\title{
Meso-scale distribution patterns of larval and pelagic juvenile fishes in the central Great Barrier Reef lagoon
}

\author{
Simon R. Thorrold*, David McB. Williams \\ Australian Institute of Marine Science, PMB No. 3, Townsville M.C., Queensland 4810, Australia, \\ and \\ Department of Marine Biology, James Cook University, Townsville, Queensland 4811, Australia
}

\begin{abstract}
Larval and pelagic juvenile fish were collected along 2 transects within the central Great Barrier Reef lagoon, Australia, using plankton nets and light traps in October, November and December 1989. Multivariate analyses were used to examine spatio-temporal variability in the distributions of the fish collected with both techniques. Plankton nets revealed a relatively stable cross-lagoon pattern, with (1) a distinctive nearshore component characterized by gobiids, callionymids, leiognathids and teraponids; (2) a cross-lagoon group including nemipterids, carangids, platycephalids and scorpaenids; and (3) an outer-lagoon assemblage dominated by clupeids, lutjanids, pomacentrids, and scombrids. Significant temporal coherence in the abundance patterns of a number of families with cross-lagoon and offshore affinities was also detected. This coherence could have been generated by either a synchronous spawning event, or by hydrographic phenomena acting over synoptic scales of at least $50 \mathrm{~km}$ in both alongshore and cross-shelf directions. Light trap catches were much more ephemeral than those from the plankton nets, and were dominated by collections at a single station in October. Numbers of principal taxa at this station were varlable on each of the 3 sampling occasions during the month. The most numerous taxa, Pomacentrus spp., were captured in high numbers on all of the 3 nights. Lethrinus spp. and Chromis sp. were abundant on the second night, but low numbers were taken on the first and third nights. Mullids were captured in progressively higher numbers through the sampling period. Comparison of plankton net and light trap data suggested that multi-specific patches of reef fish larvae were characteristic only of late-larval and pelagic juvenile stages. Patch generation may, therefore, be due to active aggregation rather than passive accumulation of larvae. Although the ultimate fate of late-stage larvae within this multi-specific patch was unknown, the data are consistent with the hypothesis that major settlement events occur when occasional dense patches of larvae collide with reef habitats.
\end{abstract}

KEY WORDS: Fish larvae Pelagic juveniles - Plankton nets - Light traps Spatio-temporal distributions

\section{INTRODUCTION}

Fisheries biologists have recognised since the beginning of the century that the population dynamics of many marine fish species may be driven by events occurring during the larval phase of the life cycle (Hjort 1914, Houde 1987). While the larval phase is restricted temporally to a period of weeks or months, extremely high mortality rates and considerable dispersive abili-

- Present address: Applied Marine Research Laboratory, Old Dominion University, Norfolk, Virginia 23529, USA.

E-mail: thorrold@estuary.amrl.odu.edu ties suggest that this stage may have a disproportionate influence on the local abundance of adult populations (Roughgarden et al. 1988). Despite the potential for larval dynamics to influence population structure, the early life history of tropical marine fishes has only recently attracted attention (Leis 1991a).

Almost all studies of larval fish distributions within tropical environments have focused on broadscale surveys (reviewed by Leis 1991a). These reports have provided valuable information on the larval habitat requirements of a number of tropical fishes, but with either limited spatial or temporal resolution. The few investigations that have been conducted on smaller 
spatial scales have addressed specific questions regarding vertical distributions (Leis 1991b), or nearreef distribution patterns (Kobayashi 1989, Lyczkowski-Shultz et al. 1990, Boehlert et al. 1992, Williams \& English 1992). While such studies are a necessary prerequisite to any understanding of larval biology, little remains known of the processes influencing larvae over 'meso' spatial and temporal scales (days-weeks and $1-10$ 's of $\mathrm{km}$ ). Paradoxically, it is variability over these scales that may be critical to larval survival and recruitment (Peterman \& Bradford 1987, Davis et al. 1991, Maillet \& Checkley 1991).

The reliance on towed-net technology for sampling larval and pelagic juvenile fish has also restricted the size range collected by larval surveys. While plankton nets sample small larval fish effectively, the activity associated with towing nets through the water column apparently leads to detection and avoidance of the net by agile nekton (Barkley 1964, Choat et al. 1993). Larger nets devised to counter active avoidance have met with limited success (Clarke 1983, Munk 1988). This presents real problems in the tropics. Many coral reef fish have a pelagic juvenile stage with considerable sensory and locomotory abilities (Leis \& Rennis 1983, McCormick \& Shand 1992) which is not adequately sampled by plankton nets or mid-water trawls (Choat et al. 1993).

Sampling of the motile component of planktonic assemblages has recently improved with the development of light traps, an alternative methodology that targets the late-larval and pelagic juvenile stages of coral reef fishes (Doherty 1987a). Initially applied to monitor larval supply to reef habitats (Milicich \& Doherty 1994), light traps have also proved useful for collecting larval and juvenile fishes in open waters (Thorrold 1992a). While the traps are effective collectors of large planktonic individuals, they appear to under-sample the smaller stages that are collected in plankton nets (Choat et al. 1993). This suggests that a sampling strategy combining both plankton nets and light traps would result in a more complete description of the distribution and abundance patterns of presettlement fishes than either technique in isolation. Despite petitions for multi-gear sampling strategies from several authors (Omori \& Hamner 1982, Kingsford 1990), such programs have rarely been undertaken (Gregory \& Powles 1988).

This study was designed to examine variability in larval and juvenile fish distributions over a range of spatial and temporal scales utilising a muiti-gear sampling strategy. Our objective was to describe mesoscale spatial (10's of $\mathrm{m}$ to $10^{\prime} \mathrm{s}$ of $\mathrm{km}$ ) and temporal (days to months) variability in larval and pelagic juvenile fish assemblages. By using both towed nets and light traps we hoped to obtain a more complete description of distribution patterns of larval and juvenile fishes than could have been achieved by a singlegear study. We hypothesized that the scales over which larval fish assemblages varied would also identify the critical spatio-temporal scales of physical and biological processes that generated the observed patterns.

\section{MATERIALS AND METHODS}

Sample collection. Field work was conducted in coastal waters of the central Great Barrier Reef (GBR), at each of 4 stations approximately $16 \mathrm{~km}$ apart, along 2 cross-shelf transects (LR and CB) during OctoberDecember 1989 (Fig. 1). One transect could be completed in a single night of sampling, and each transect was sampled at least once, and up to 3 times, in each of the 3 months depending on weather conditions. All sampling was conducted within a $10 \mathrm{~d}$ window around the new moon. Sampling equipment consisted of a $0.5 \mathrm{~m}$ diameter plankton net fitted with $0.505 \mathrm{~mm}$ mesh and a General Oceanics digital flowmeter, and light traps as described in Thorrold (1993a). At each station 6 light traps were deployed, 200 to $300 \mathrm{~m}$ apart and approximately $1 \mathrm{~m}$ below the sea surface, and fished for $1 \mathrm{~h}$. The traps were allowed to drift with the prevailing currents rather than being moored to the bottom. While this reduced the amount of water the trap sampled, it also reduced the possibility of variable current flows across the traps confounding differences

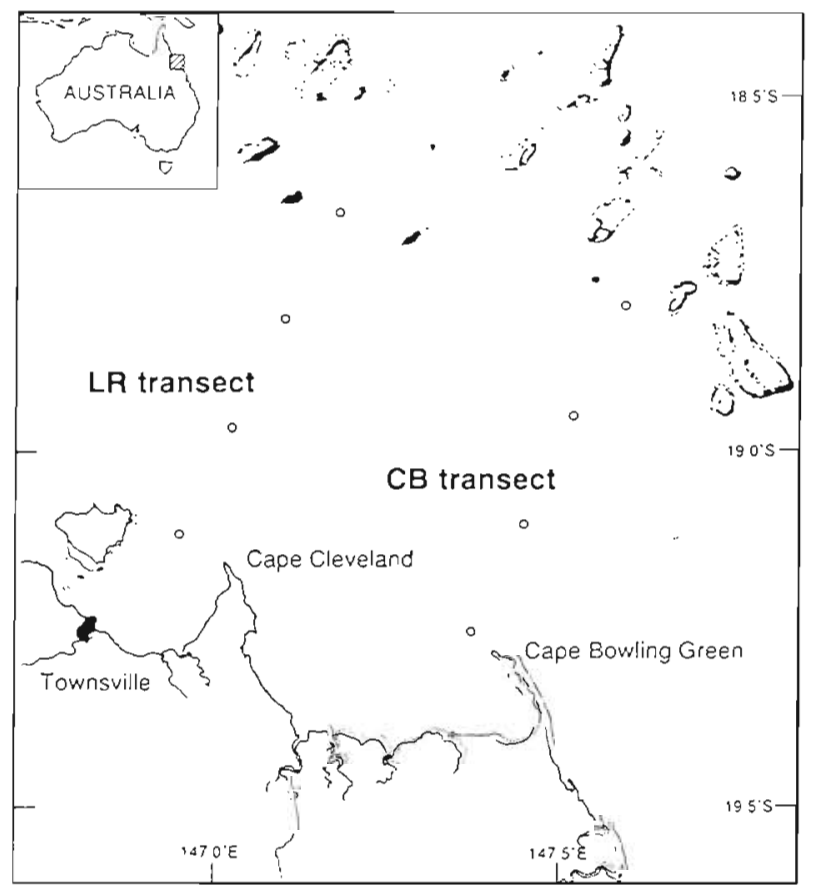

Fig. 1. Locality map showing positions of stations (o) on the LR and $C B$ transects in the central Great Barrier Reef lagoon 
among stations and across sampling occasions. Three plankton tows, each of 10 min duration, were made in the immediate vicinity of the traps during the period that the light traps were fishing. The $0.5 \mathrm{~m}$ net was set to fish between 1 and $2 \mathrm{~m}$ below the surface, and towed at between 0.5 and $1 \mathrm{~m} \mathrm{~s}^{-1}$.

Samples were immediately preserved in $80-90 \%$ ethanol for subsequent identification and enumeration. Larvae collected in the plankton net were identified to family level, following Leis \& Rennis (1983) and Leis \& Trnski (1989). Fish collected in the light traps were identified to the lowest possible taxon. However, for all statistical analyses the light trap identifications were truncated at the same taxonomic level as that obtained in the net tows. Numbers of larvae collected in net samples were converted to concentrations (numbers $100 \mathrm{~m}^{-3}$ ) using the volumes of water sampled calculated from the flowmeter data, while samples from the light traps were expressed as numbers of fish per lighttrap-hour.

Data analysis. We conducted multivariate analyses of the distribution patterns of fish collected with both plankton nets and light traps. A Bray-Curtis dissimilarity matrix was generated from the family/sample data set. The dissimilarity matrix was then used as the basis for a flexible unweighted (UPGMA) clustering strategy. The family/sample matrix was also transposed and families clustered using a flexible UPGM 1 A. In this case, the dissimilarity matrix was again generated using the Bray-Curtis algorithm after the data had first been standardized by expressing each value as a proportion of the maximum value recorded for that family This standardization is commonly used when attributes (in this case families) rather than objects (i.e. the individual samples) are clustered (Belbin 1988). Bubble plots were used to display the associations of samples between transects, and among months and stations. These plots were generated by calculating the percentage of samples from a given month, transect and station within the sample group under consideration. Results of clustering by samples and families were plotted using 2-way table summaries (Smith et al. 1989). The 'bubbles' in the resulting 2 -way summary plots represent the percentages of the species groups upon summing the mean proportions of each family group across columns or down rows. The directions in which these summations were calculated are shown by arrows on the appropriate plots.

The above techniques are powerful methods for displaying patterns of association in multivariate data sets. However they are unable to test specific hypotheses concerning the spatial and temporal variability in taxonomic composition or abundance. Both plankton net and light trap data consisted of a multivariate family/sample matrix with nights nested within transects, and transect, month and station as main factors in a 3 way, mixed model ANOVA design. A number of difficulties arise if multivariate ANOVA is used to analyse the data sets, including the non-normality typical of plankton data (Mackas et al. 1985). Assumptions underlying parametric MANOVA include normal distributions of individual taxa and equal variance-covariance matrices. To overcome these problems, Mantel (Mantel 1967) and partial Mantel tests (Smouse et al. 1986) were used instead. These tests use a non-parametric, permutation method to determine statistical significance and therefore are not invalidated by nonnormality.

The Bray-Curtis dissimilarity matrices used in the preceding cluster analyses formed the data matrix for the Mantel and partial Mantel tests, with each alternative hypothesis of the analysis of variance (i.e. no effect of station, transect and time on ichthyoplankton associations) cast into a model matrix. For instance the model matrix expressing the alternative hypothesis that there were differences among stations contained 1's in the within-station regions of the matrix, and 0 's elsewhere. Similarly, the model matrix that represented differences among times contained 1's in the cells comparing the same times, and 0 's in the among-time cells. An empirical null distribution was derived from randomly permuting one of the matrices 500 times, and the probability of obtaining a value of $r$ at least as extreme as the observed $r$ by chance alone was computed. All tests were 2 -tailed, with an $\alpha$ value of 0.05 . The test for interactions between main effects followed that described by Smouse et al. (1986). Mantel and partial Mantel tests were run using 'the R package for multivariate data analysis' of Legendre and Vaudor, referred to in Legendre \& Fortin (1989).

Further univariate analyses were conducted on the families contributing most to the station-time groups in cluster analyses, as determined by examining Cramer values derived from the cluster analysis $\mathrm{Bel}$ bin 1988). The top 5 taxa contributing most to the cluster groupings from both light traps and net tows were selected for further univariate analyses. ANOVA was used to examine variability at each of the spatial and temporal scales sampled. Although the experimental design called for both transects to be sampled 3 times in each month, bad weather in December meant that only 1 night of sampling could be completed on each transect. Therefore, nights were pooled within months in October and November. After pooling, a 3-factor, orthogonal ANOVA was used to test for differences between months, transects and stations. As there was uneven replication (3 nights of sampling from October and November for a total of 9 replicates, 1 night for a total of 3 replicates from December), type III sums of squares were used 
Table 1. Frequency and percent frequency by famıly of larval fishes collected in plankton nets from October to December 1989

\begin{tabular}{|c|c|c|c|c|c|c|c|c|}
\hline Family & Freq & $\%$ freq. & Family & Freq. & $\%$ freq & Family & Freq. & $\%$ freq. \\
\hline Gobiidae & 5681 & 40.6 & Blenniidae & 53 & 0.4 & Paralicthyidae & 5 & - \\
\hline Apogonidae & 1.117 & 7.9 & Mugilidae & 49 & 0.4 & Balistidae & 4 & - \\
\hline Clupeidae & 1048 & 7.5 & Sphyraenidae & 48 & 0.3 & Letobramidae & 4 & -- \\
\hline Lutjanidae & 983 & 7.0 & Polynemidae & 36 & 0.3 & Pomacanthidae & 4 & - \\
\hline Carangidae & 672 & 4.8 & Serranidae & 33 & 02 & Psettodidae & 4 & - \\
\hline Nemipteridae & 559 & 4.0 & Syngnathidae & 33 & 0.2 & Sillaginidae & 4 & - \\
\hline Teraponidae & 351 & 2.5 & Myctophidae & 30 & 0.2 & Trichiuridae & 4 & - \\
\hline Pomacentridae & 290 & 2.1 & Engraulidae & 28 & 0.2 & Ammodytidae & 3 & - \\
\hline Monacanthidae & 288 & 2.1 & Cynoglossidae & 24 & 0.2 & Fistulariidae & 3 & - \\
\hline Bregmacerotide & 282 & 2.0 & Holocentridae & 23 & 0.2 & Pleuronectidae & 3 & - \\
\hline Leiognathidae & 256 & 1.8 & Scaridae & 23 & 0.2 & Pseudochromide & 3 & - \\
\hline Scombridae & 251 & 1.8 & Opistognathidae & 20 & 0.1 & Scatophagidae & 3 & - \\
\hline Callionymidae & 230 & 1.6 & Diodontidae & 16 & 0.1 & Carapidae & 2 & - \\
\hline Platycephalidae & 182 & 1.3 & Acanthuridae & 13 & 0.1 & Hemiramphidae & 2 & - \\
\hline Bothidae & 134 & 1.0 & Exocoetidae & 12 & 0.1 & Istiophoridae & 2 & - \\
\hline Mullidae & 131 & 0.9 & Haemulidae & 11 & 0.1 & Kyphosidae & 2 & - \\
\hline Priacanthidae & 124 & 0.9 & Mugiloididae & 10 & 0.1 & Ostraciidae & 2 & - \\
\hline Scorpaenidae & 102 & 0.7 & Belonidae & 9 & 0.1 & Soleidae & 2 & - \\
\hline Labridae & 80 & 0.6 & Lophiiformes & 9 & 0.1 & Tripterygiidae & 2 & - \\
\hline Schindleriidae & 73 & 0.5 & Gerridae & 8 & 0.1 & Cepolidae & 1 & - \\
\hline Lethrinıdae & 73 & 0.5 & Trichonotidae & 8 & 0.1 & Gemphylidae & 1 & - \\
\hline Tetraodontidae & 72 & 0.5 & Leptocephali & 7 & 0.1 & Nomeidae & 1 & -- \\
\hline Synodontidae & 63 & 0.4 & Triacanthıdae & 7 & 0.1 & Siganidae & 1 & - \\
\hline Microdesmidae & 55 & 0.4 & Chaetodontidae & 5 & - & Unidentified & 242 & 1.7 \\
\hline Sciaenidae & 54 & 0.4 & Dactylopteridae & 5 & - & Total & 13998 & 100 \\
\hline
\end{tabular}

for all ANOVA analyses. All variables were tested for heterogeneity of variances and normality of residuals using residual analysis (Winer 1971).

\section{RESULTS}

A total of 13988 larvae were captured in 168 plankton tows, while the light traps collected 3781 fish from a total of 419 light-trap-hours. Catches from plankton nets and light traps showed distinctive taxonomic com- positions. In the net tows, 75 families were collected, while the light traps captured 36 families. Plankton net samples were dominated by gobiids, with apogonids, clupeids, lutjanids and carangids making up the 5 most abundant taxa (Table 1). Numerically, these 5 taxa accounted for $68 \%$ of the total number of larvae collected. Pomacentrids were the most abundant family captured in the light traps, representing almost $50 \%$ of the entire catch (Table 2). Lethrinids, clupeids and mullids were the only other taxa that accounted for more than $1 \%$ of the total catch.

Table 2. Frequency and percent frequency by family of late-stage larval and pelagic juvenile fishes captured in light traps from October to December 1989

\begin{tabular}{|c|c|c|c|c|c|c|c|c|}
\hline Family & Freq. & $\%$ freq. & Family & Freq. & $\%$ freq. & Family & Freq & $\%$ freq \\
\hline Pomacentridae & 1814 & 48.0 & Carangidae & 16 & 0.4 & Diodontidae & 4 & 0.1 \\
\hline Lethrinidae & 962 & 25.4 & Siganidae & 16 & 0.4 & Plesiopidae & 3 & 0.1 \\
\hline Clupeidae & 346 & 9.8 & Monacanthidae & 13 & 0.3 & Bregmacerotidae & 2 & 0.1 \\
\hline Mullidae & 218 & 5.8 & Syngnathidae & 13 & 0.3 & Fistularidae & 1 & - \\
\hline Dactylopteridae & 70 & 1.9 & Priacanthidae & 10 & 0.3 & Lutjanidae & 1 & - \\
\hline Blenniidae & 69 & 1.9 & Trupterygiidae & 10 & 0.3 & Myctophidae & 1 & - \\
\hline Engraulidae & 44 & 1.2 & Gerreidae & 8 & 0.2 & Nemipteridae & 1 & - \\
\hline Atherinidae & 35 & 0.9 & Gobiidae & 8 & 0.2 & Ostraciidae & 1 & - \\
\hline Apogonidae & 30 & 0.8 & Labridae & 7 & 0.2 & Scaridae & 1 & - \\
\hline Scombridae & 21 & 0.6 & Synodontidae & 6 & 0.2 & Serranidae & 1 & - \\
\hline Tetraodontidae & 19 & 0.5 & Chaetodontidae & 5 & 0.1 & Sphyraenidae & 1 & - \\
\hline Scorpaenudae & 18 & 0.5 & Holocentridae & 5 & 0.1 & $\begin{array}{c}\text { Teraponidae } \\
\text { Total }\end{array}$ & $\begin{array}{r}1 \\
3781\end{array}$ & $\begin{array}{c}- \\
100\end{array}$ \\
\hline
\end{tabular}




\section{Plankton nets}

Cluster analysis of the plankton net data using the Bray-Curtis dissimilarity matrix and an UPGMA clustering strategy detected 4 main sample groups (Fig 2). The first split (group 1) identified samples collected principally from October and November, on both transects, and almost exclusively from the $0 \mathrm{~km}$ station. Group 2 showed similar temporal affinities to group 1, but was spread almost evenly across the 3 offshore stations, again on both transects. Group 3 was collected almost exclusively in November, from the $16 \mathrm{~km}$ and $32 \mathrm{~km}$ stations on both transects. Finally, samples from group 4 came from December, and largely from the 3 offshore stations.

Clustering by families revealed 3 major taxonomic groupings (Fig. 3). Family group 1 included apogonids, callionymids, gobiids, leiognathids and teraponids. This group showed highest affinity with sample group 1 from the station-time cluster, which was in turn restricted to inshore stations. Family group 2 consisted of bothids, bregmacerotids, monacanthids, nemipterids, platycephalids, priacanthids and scorpaenids. This group was associated with sample groups 1 and 4 , and from stations spanning the entire lagoon. Family
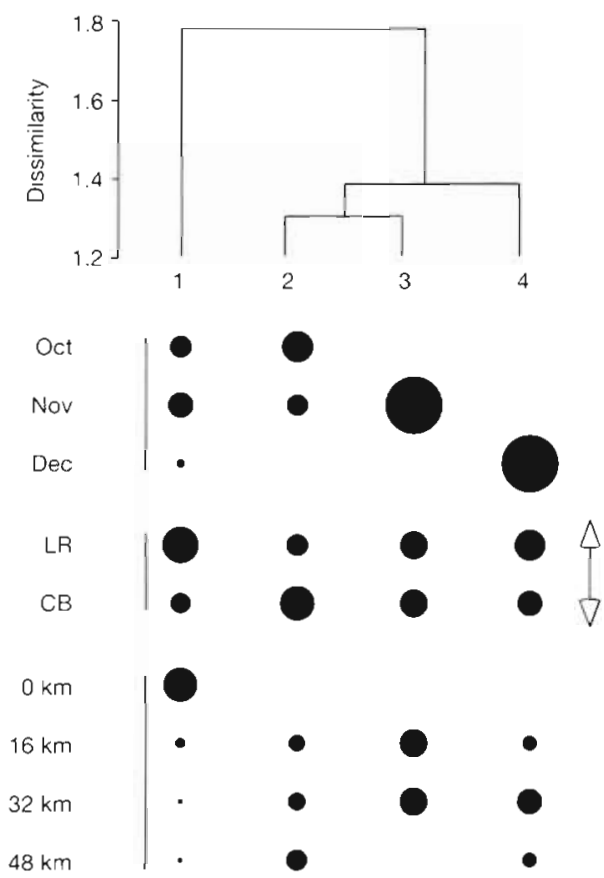

Fig. 2. Summary of UPGMA cluster analysis for net tow data, showing the relationship of temporal and spatial factors to cluster groupings. The symbols represent the percentage of a sample group which occurs in each month, on each transect, and among stations. Percentages within each of these factors add to $100 \%$. Arrow indicates direction in which these percentages were summed

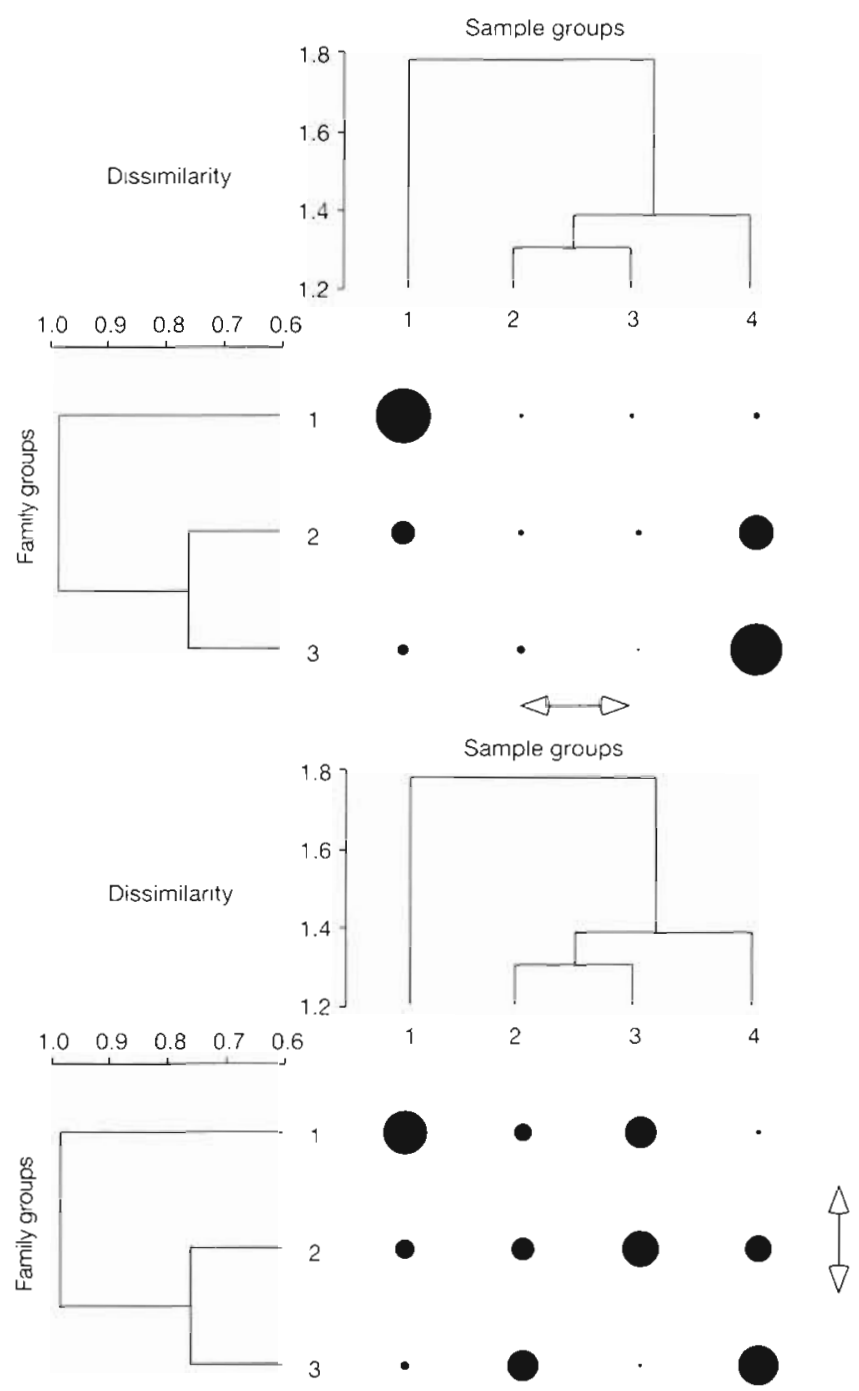

Fig. 3. Summary of cluster analyses of sample and family groups for net tow data. Upper table displays the distribution of sample groups within family groups (rows sum to $100 \%$ in direction of arrow); lower table shows the distribution of family groups within sample groups (columns sum to $100 \%$ in direction of arrow). Symbols represent the percentage of a family group withın a sample group

group 3 included carangids, clupeids, lutjanids, mullids, pomacentrids and scombrids. This family group was largely restricted to sample group 4, at stations 16 to $48 \mathrm{~km}$ from the coast.

Mantel's and partial Mantel's tests were used to more rigorously assess variability in the data over the range of spatio-temporal scales considered. Significant variability was found over almost all spatio-temporal scales examined (Table 3). All main factors, except transect, were significant. The matrix containing station effects showed the highest correlation with the data matrix ( $r=0.251)$. Night and month showed similar correlations ( $r=0.103$ and $r=0.094$ respectively). with transects not significantly correlated $(r=0.023)$. 
Table 3. Results of Mantel and partial Mantel tests against tempotal and spatial models of variability in the numbers of fish captured in plankton nets, where $r=$ Mantel's test statistic of matrix correspondence, ST is the number of times that the re-calculated test statistic, after the model matrix is randomly permuted, is smaller than the original $r$ value, EQ is the number of times this value is equal to $r_{1}$ and $G T$ is the number of times that this value is greater than $r$. Prob(t) is the probability of the null hypothesis being true. ns: not significant at

$$
\alpha=0.05
$$

\begin{tabular}{|lccccc|}
\hline & $I$ & ST & EQ & GT & Prob $(t)$ \\
\hline Temporal & & & & & \\
Night & 0.103 & 500 & 1 & 0 & 0.002 \\
Month & 0.094 & 500 & 1 & 0 & 0.002 \\
Spatial & & & & & \\
Transect & 0.023 & 493 & 1 & 7 & $0.016^{\text {ns }}$ \\
Station & 0.251 & 500 & 1 & 0 & 0.002 \\
Interactions & & & & & \\
Month $\times$ station & 0.101 & 500 & 1 & 0 & 0.002 \\
Station $\times$ month & 0.254 & 500 & 1 & 0 & 0.002 \\
Month $\times$ transect & 0.094 & 500 & 1 & 0 & 0.002 \\
Transect $\times$ mionth & 0.027 & 494 & 1 & 6 & $0.014^{n s}$ \\
Transect $\times$ station & 0.026 & 498 & 1 & 2 & 0.006 \\
Station $\times$ transect & 0.259 & 500 & 1 & 0 & 0.002 \\
& & & & & \\
\hline
\end{tabular}

Not surprisingly most first order interactions were also significant. The only non-significant interaction was the transect $\times$ month term. Again the interaction terms emphasized variability at the station, and then month, level of the data set.

Examination of Cramer values suggested that 5 taxa contributed most to sample groupings found in the UPGMA clustering. These taxa were, in descending order of Cramer values, gobiids, lutjanids, apogonids, clupeids and nemipterids. After residual analysis revealed that variances of these taxa could be considered homogeneous, a 3-factor ANOVA, with month, station and transect as main effects, was used to identify spatio-temporal scales over which these individual taxa were varying (Table 4).

Significant effects of month and station were detected in the family Gobiidae, although significant first order interactions of month $\times$ station, and transect $x$ station, suggested that the distribution patterns were complex. These differences can be seen by examination of 3-dimensional graphs of mean gobild concentrations (i.e. 'cell means') plotted against station and month. The CB transect showed a consistent pattern in all 3 months of sampling (Fig 4). Gobiid larvae were found in high numbers at the inshore station, and in typically low numbers at all stations further offshore. Gobiid distributions on the LR transect were much more variable. In October, numbers were highest at the inshore station, very low at the $16 \mathrm{~km}$ station, and intermediate at the 32 and $48 \mathrm{~km}$ stations. In Novem-
Table 4. Summary table of 3-factor ANOVA for 5 families of larval fishes collected in plankton tows from the central Great Barrier Reef lagoon. ns: not significant with $\alpha=0.05$

\begin{tabular}{|c|c|c|c|}
\hline Source & MS & $F$-value & Prob. \\
\hline \multicolumn{4}{|l|}{ Gobiidae } \\
\hline Month & 682610 & 7.7 & 0.001 \\
\hline Transect & 29446 & 0.3 & $0.57^{\mathrm{ns}}$ \\
\hline Station & 264853 & 29.8 & 0.001 \\
\hline Month $\times$ transect & 58618 & 0.7 & $0.52^{n s}$ \\
\hline Month $\times$ station & 400074 & 4.5 & 0.001 \\
\hline Transect $\times$ station & 259602 & 2.9 & 0.04 \\
\hline Month $\times$ transect $\times$ station & 115221 & 1.3 & $0.26^{\mathrm{ns}}$ \\
\hline \multicolumn{4}{|l|}{ Lutjanidae } \\
\hline Month & 374548 & 239 & 0.0001 \\
\hline Transect & 376 & 0.2 & $0.62^{\mathrm{ns}}$ \\
\hline Station & 55724 & 35.7 & 0.0001 \\
\hline Month $\times$ transect & 731 & 0.5 & $0.63^{\text {ns }}$ \\
\hline Month $\times$ station & 22755 & 14.6 & 0.0001 \\
\hline Transect $\times$ station & 128752 & 82.4 & 0.0001 \\
\hline Month $\times$ transect $\times$ station & 65777 & 42.1 & 0.0001 \\
\hline \multicolumn{4}{|l|}{ Apogonidae } \\
\hline Month & 38581 & 20.2 & 0.0001 \\
\hline Transect & 3148 & 1.6 & $0.20^{\mathrm{ns}}$ \\
\hline Station & 3451 & 1.8 & $0.15^{\text {ns }}$ \\
\hline Month $\times$ transect & 1548 & 0.8 & $0.45^{\mathrm{ns}}$ \\
\hline Month $\times$ station & 6813 & 3.6 & 0.01 \\
\hline Transect $\times$ station & 21719 & 11.4 & 0.0001 \\
\hline Month $\times$ transect $\times$ station & 8324.8 & 4.4 & 0.001 \\
\hline \multicolumn{4}{|l|}{ Clupeidae } \\
\hline Month & 174034 & 68.5 & 0.0001 \\
\hline Transect & 32587 & 12.8 & 0.001 \\
\hline Station & 14505 & 5.7 & 0.001 \\
\hline Month $\times$ transect & 46300 & 18.2 & 0.0001 \\
\hline Month $\times$ station & 14908 & 5.9 & 0.0001 \\
\hline Transect $\times$ station & 481.54 & 19 & 0.0001 \\
\hline Month $\times$ transect $\times$ station & 19258 & 7.6 & 0.0001 \\
\hline \multicolumn{4}{|l|}{ Nemipteridae } \\
\hline Month & 50380 & 115 & 0.0001 \\
\hline Transect & 122 & 0.3 & $0.60^{\mathrm{ns}}$ \\
\hline Station & 12083 & 27.7 & 0.0001 \\
\hline Month $\times$ transect & 1760 & 4.0 & 0.02 \\
\hline Month $\times$ station & 5040 & 11.5 & 0.0001 \\
\hline Transect $\times$ station & 20104 & 46 & 0.0001 \\
\hline Month $\times$ transect $\times$ station & 13387 & 30.7 & 0.0001 \\
\hline
\end{tabular}

ber, gobiid larvae were concentrated at the inshore station while in December maximum numbers were recorded at the $16 \mathrm{~km}$ station.

Lutjanids exhibited significant effects of month and station, with a non-significant effect of transect (Table 4). All first order, and the single second order. interactions were also highly significant. Lutjanidae larvae were much more abundant in December than in either October or November (Fig. 4). Larvae were captured across the lagoon, although they were more prevalent at the offshore stations on both transects. In October and November, larvae were largely restricted to the $32 \mathrm{~km}$ and $48 \mathrm{~km}$ stations. 
Fig. 4. Mean concentration ( \pm standard error) of larvae from net tows at stations across the central Great Barrier Reef on the LR transect (solid bars) and $C B$ transect (shaded bars), October to December 1989. for the families Gobildae, Lutjanidae, Apogonidae, Clupeidae and Nemipteridae
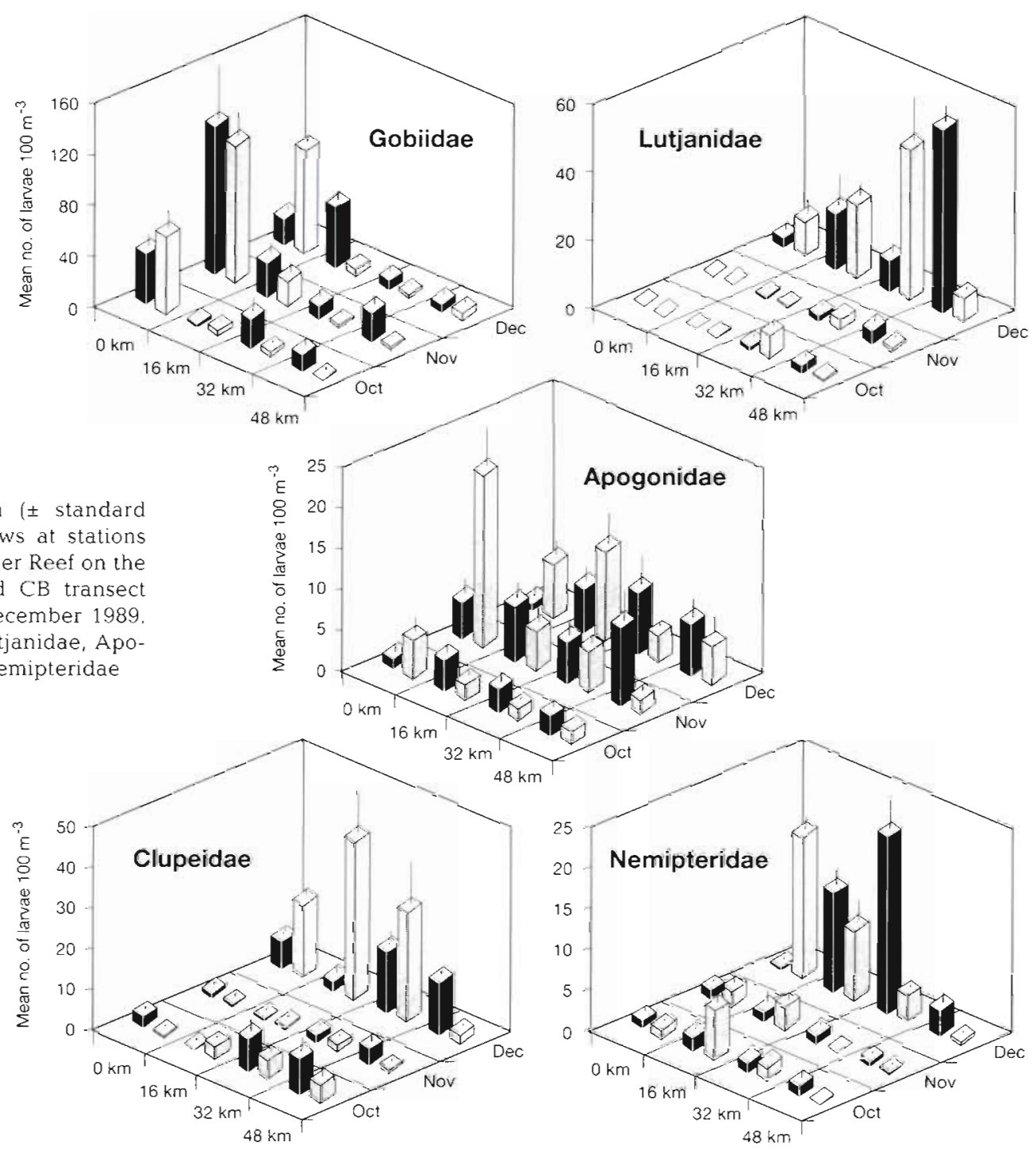

The only significant main effect for the family Apogonidae was that of month. The presence of 2 significant first order interactions (month $\times$ station and transect $\times$ station) and a significant second order interaction meant, however, that this effect could not be interpreted in isolation. Apogonid larvae were, in fact, distributed relatively homogeneously across months, stations and transects (Fig. 4). A single peak in abundance at the $0 \mathrm{~km}$ station in November on the CB transect appeared to account for a considerable amount of the variance.

Larval concentrations of clupeids were, in contrast to the apogonids, extremely patchy. The 3 main effects and all interaction terms in the ANOVA were highly significant. Larvae were relatively abundant in December on the CB transect but, unlike the lutjanids, this trend was not apparent on the LR transect in this month (Fig 4). The $16 \mathrm{~km}$ station contributed the low- est numbers in all months on the LR transect. Again however, this pattern was not seen on the CB transect.

All main effects and interaction terms were significant for nemipterid larvae, with the exception of the effect of transect. Numbers were dominated by samples taken at several stations in December, on both transects (Fig. 4). On the CB transect, numbers were highest inshore, while on the LR transect numbers peaked at the 16 and $32 \mathrm{~km}$ stations. Concentrations were reasonably similar across all stations in October and November, although they were slightly higher at the 2 inshore stations on the CB transect.

\section{Light traps}

Light trap data were subjected to the same multivariate analyses as those outlined above for the net tow 
samples. Cluster analysis of the Bray-Curtis dissimilarity matrix generated from the family/sample data matrix revealed 4 distinct groupings (Fig. 5). Groups 1 and 2 consisted of samples from October and November respectively, almost equally on both transects, and spread relatively evenly across all stations. Group 3 represented samples from the $16 \mathrm{~km}$ station on the LR transect in October, along with 3 samples from the same station in November. Finally, samples from group 4 were taken in December, on both transects, and from the 3 offshore stations.

Clustering across families revealed 4 major groupings (Fig. 6). The first family grouping consisted of apogonids, clupeids, engraulids and scombrids. The group was largely confined to groups 1 and 2 in the sample cluster, which were distributed ubiquitously across stations and transects. The second family group consisted of a single family, the Blenniidae, and contributed mainly to sample group 1 Family group 3 was also a single taxonomic grouping, the family Dactylopteridae, and was restricted to the 16,32 and $48 \mathrm{~km}$ stations in December. Finally, family group 4 was made up of atherinids, lethrinids, pomacentrids and mullids. This group was found almost exclusively within sample group 3, from the $16 \mathrm{~km}$ station on the LR transect in October.

Mantel's and partial Mantel's tests were used to examine spatio-temporal variability in light trap
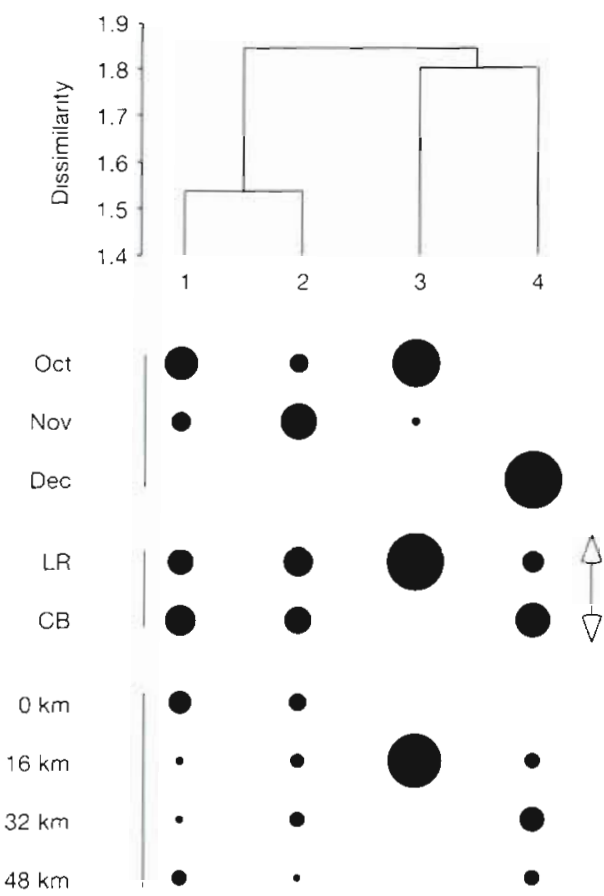

Fig. 5. Summary of UPGMA cluster analysis for light trap data, showing relationship of temporal and spatial factors to cluster groupings. Legend as for Fig. 2

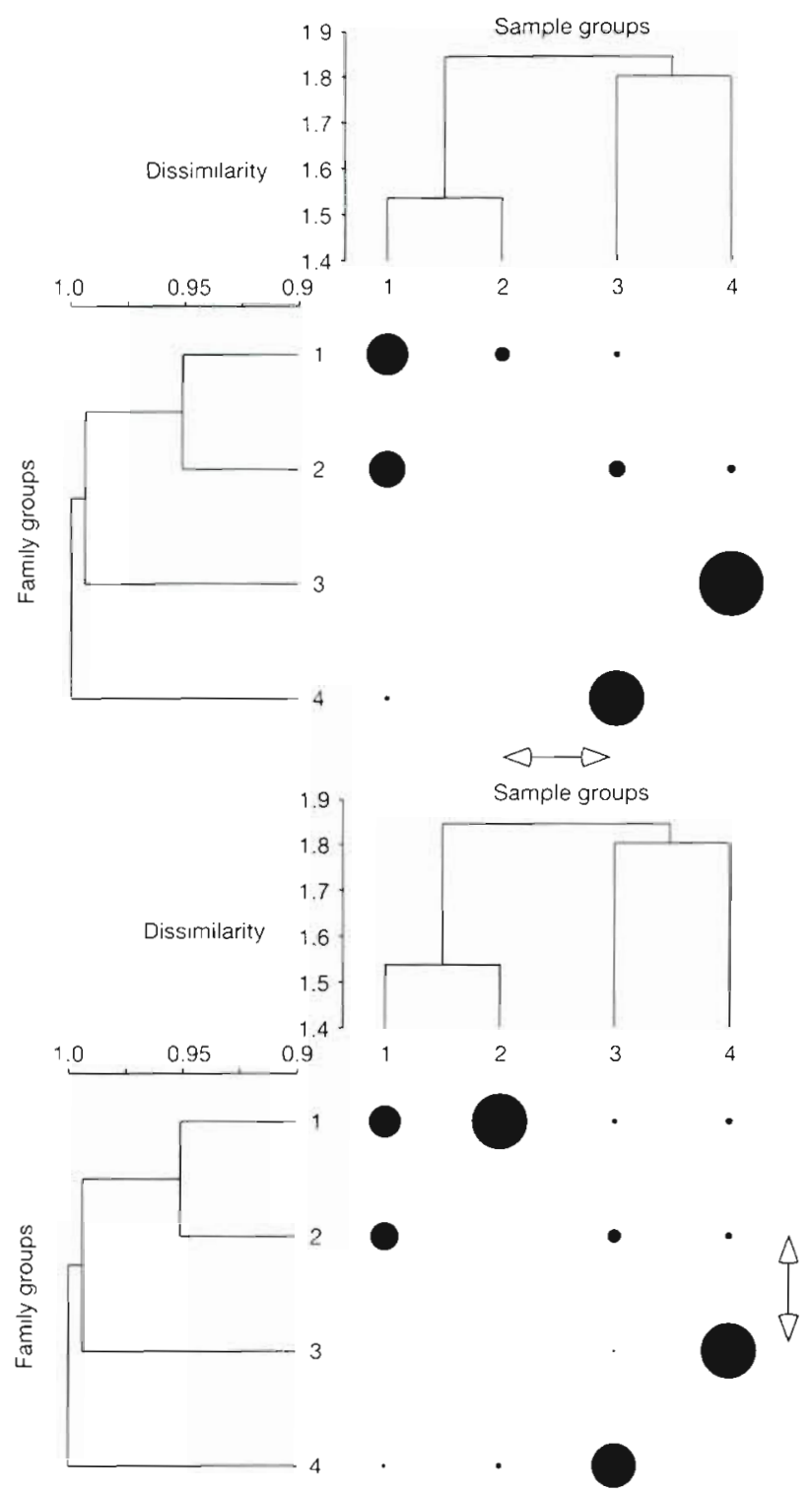

Fig. 6. Summary tables of cluster analyses of sample and family groups for light trap data. Legend as for Fig. 2

catches in more detail. Models incorporating the 4 main effects were all significant (Table 5), although correlations were higher with the temporal models ( $x=$ 0.130 for the night effect, and $r=0.196$ for the month effect) than spatial models ( $r=0.067$ effect of transect, and $r=0.100$ for effects of station). All first order interactions were also significant. Again, however, models including the month effect were more highly correlated than models with only the spatial components of transect and station.

Cramer values from the UPGMA clustering were examined to identify the 5 individual families contributing most variance to the clata matrix. These families were, in order of decreasing Cramer values, Poma- 
Table 5. Results of Mantel and partial Mantel tests against temporal and spatial models of variability in the patterns of late larval and juvenile fish distributions from light trap samples. Legend as for Table 3

\begin{tabular}{|lccccc|}
\hline & $r$ & ST & EQ & GT & Prob(t) \\
\hline Temporal & & & & & \\
Night & 0.130 & 500 & 1 & 0 & 0.002 \\
Month & 0.193 & 500 & 1 & 0 & 0.002 \\
Spatial & & & & & \\
Transect & 0.067 & 500 & 1 & 0 & 0.002 \\
Station & 0.100 & 500 & 1 & 0 & 0.002 \\
Interactions & & & & & \\
Month $\times$ station & 0.196 & 500 & 1 & 0 & 0.002 \\
Station $\times$ month & 0.101 & 500 & 1 & 0 & 0.002 \\
Month $\times$ transect & 0.196 & 500 & 1 & 0 & 0.002 \\
Transect $\times$ month & 0.066 & 500 & 1 & 0 & 0.002 \\
Transect $\times$ station & 0.057 & 500 & 1 & 0 & 0.002 \\
Station $\times$ transect & 0.101 & 500 & 1 & 0 & 0.002 \\
\hline & & & & & \\
\hline
\end{tabular}

centridae, Lethrinidae, Mullidae, Dactylopteridae, and Clupeidae. Variances of all families were intractably heterogeneous after a number of possible transformations, and hence the 3-factor ANOVAs used for the coincident net tow samples could not be employed. Interpretation of these results was based instead on 3 dimensional 'cell mean' graphs plotting light trap numbers versus month and station, for each transect (Fig. 7). These plots were identical to those produced for the net tow data in the preceding section.

Pomacentrids were numerically dominant in the light trap catch. They were, however, captured in high numbers only in October on the LR transect, at the $16 \mathrm{~km}$ station (Fig. 7). Pomacentrids were virtually absent from the CB transect throughout the sampling period. Lethrinids showed an almost identical pattern, with extremely high numbers at the $16 \mathrm{~km}$ station on the LR transect in October. Very few were captured on any other sampling occasion. Mullids also peaked at

Fig. 7. Mean numbers (+ standard error) of larvae captured by light traps at stations across the central Great Barrier Reef on the LR transect (solid bars) and $\mathrm{CB}$ transect (shaded bars), October to December 1989. for the families Pomacentridae, Lethrinidae. Mullidae, Dactylopteridae and Clupeidae
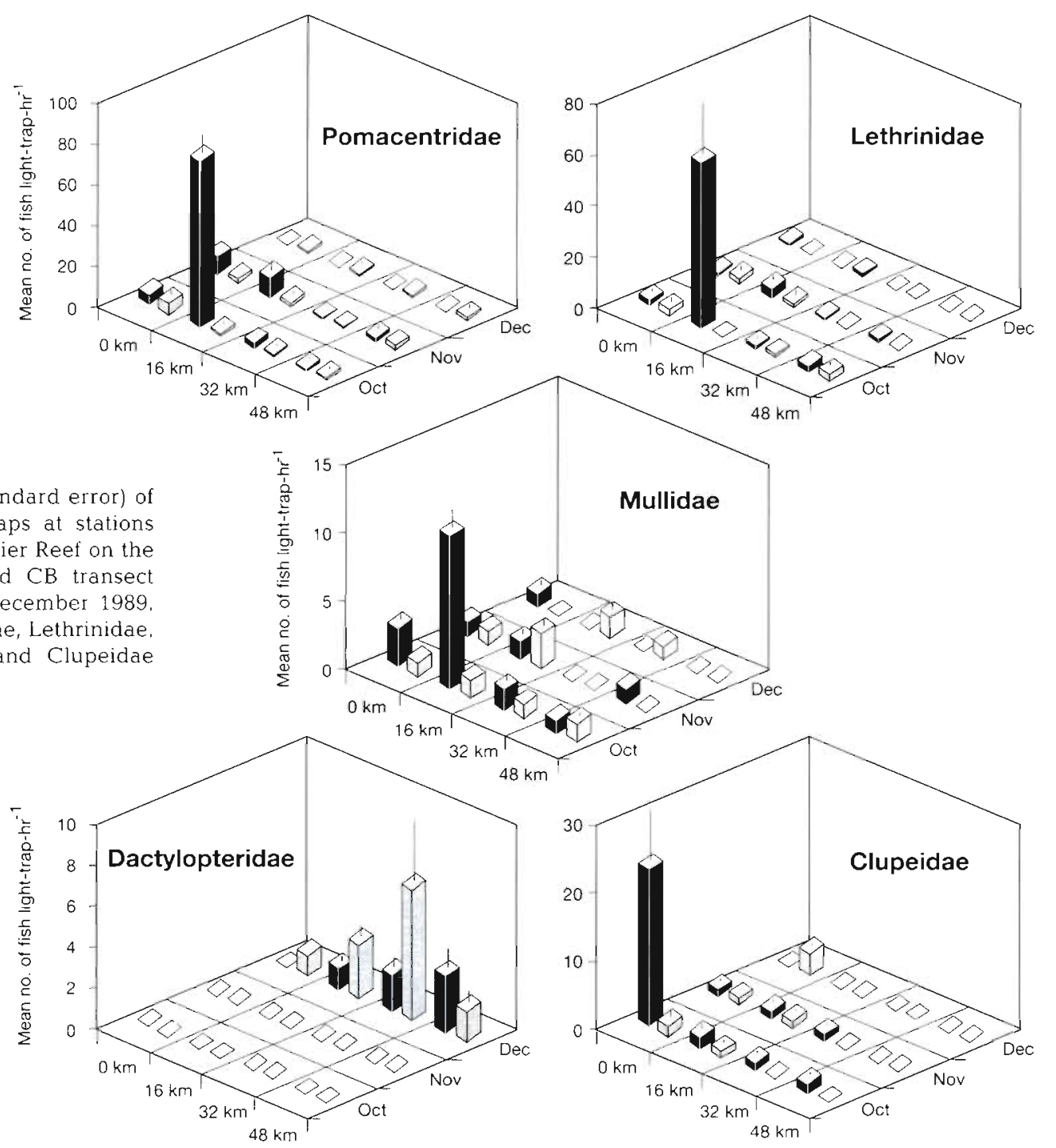


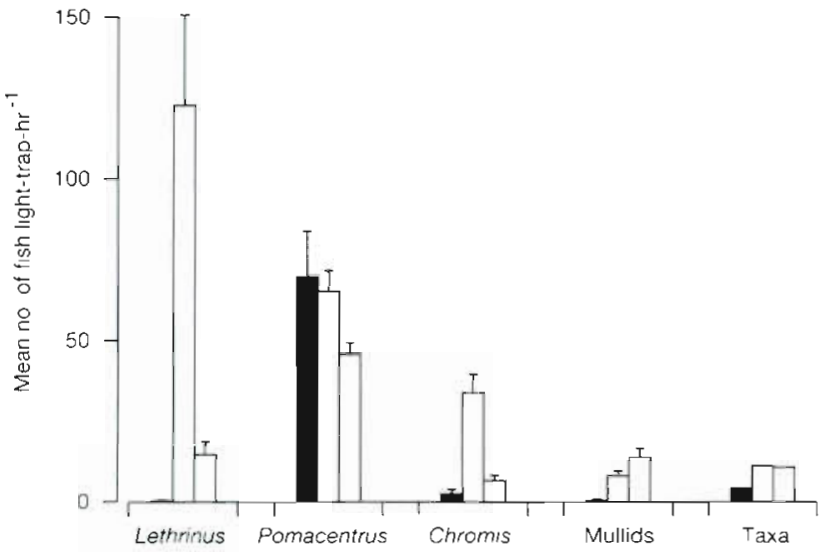

Fig. 8. Mean numbers (+ standard errors) of the 4 most abundant taxa captured by light traps at the $16 \mathrm{~km}$ station on the LR transect during 3 nights of sampling over the new moon of October 1989: Sep 25 (solid bars), Oct 3 (hatched bars), and Oct 5 (open bars)

this same place in time, although smaller numbers were captured over all 3 months, and across most stations. Dactylopterids were restricted temporally to samples from December. Unlike the preceding taxa, however, they were not concentrated at any particular station. Numbers were relatively high across the 3 of shore stations on the LR transect, and across all stations on the CB transect. Clupeids were captured across all stations, although numbers were dominated by samples at the $0 \mathrm{~km}$ station on the LR transect in October.

Several taxa were captured in high numbers at the $16 \mathrm{~km}$ station on the LR transect in October. Indeed the total of 2277 fish from this single station in October represented $60 \%$ of the total light trap catch; in the case of the family Lethrinidae, this figure was greater

Table 6. Total number of fish by taxon collected at the $16 \mathrm{~km}$. station on the LR transect in October 1989

\begin{tabular}{|c|c|c|c|}
\hline Taxon & Total & Taxon & Total \\
\hline Apogonidae & 4 & Pomacentridae (cont.) & \\
\hline Athernidae & 9 & Dischistodus sp. & 1 \\
\hline Blennidae & 1 & Neopomacentrus spp. & 4 \\
\hline Bregmacerotidae & 2 & Plectroglyphidodon & 9 \\
\hline Carangidae & 10 & Pomacentrus spp. & 940 \\
\hline Chaetodontidae & 3 & Pristotis jerdoni & 11 \\
\hline Clupeidae & 5 & Scombridae & \\
\hline Engraulidae & 2 & Scomberomorus sp. & 1 \\
\hline Gerreidae & 5 & Scorpaenıdae & 14 \\
\hline Lethrinidae & & Siganidae & 4 \\
\hline Lethrinus spp. & 838 & Syngnathidae & 9 \\
\hline Monacanthidae & 6 & Synodontidae & 4 \\
\hline Mullidae & 134 & Syphraenidae & 1 \\
\hline Pomacentridae & & Tetraodontidae & 7 \\
\hline Chromis sp. & 253 & Total & 2277 \\
\hline
\end{tabular}

than $90 \%$. Numbers of the principal taxa were variable, however, on each of the 3 nights within October (Fig. 8). Pomacentrus spp. were the most numerous taxa, and were captured in high numbers on all 3 nights. Lethrinids were abundant on the second night, with much lower numbers collected on nights 1 and 3 . Chromis sp. showed a similar pattern to the lethrinids, with highest abundance on night 2. Mullids, however, were captured in progressively higher numbers through the sampling period. While these 4 taxa dominated numbers numerically, a number of rare taxa were also taken at the $16 \mathrm{~km}$ station during October (Table 6). Chaetodontids, gerreids and monacanthids were all represented in samples from this time.

\section{Comparison of towed net and light trap distributions}

Comparison of distribution patterns of larval and juvenile fish collected by towed nets and light traps were hampered by 2 factors. Taxonomic differences between techniques meant that only 3 families (pomacentrids, clupeids and muliids) were captured in sufficient numbers (a total of at least 100 individuals taken by each method) for any meaningful comparison to be made. Intractably heterogeneous variances from the light trap data also invalidated the ANOVA model that was used to quantify spatio-temporal variability from the towed net samples. Therefore comparisons were based on the 3-dimensional plots of cell means (Fig. 9). Pomacentrid, clupeid and mullid larvae were largely restricted to the outer 3 stations on both transects in all 3 months, although significant numbers of all 3 families were taken in the inshore station on the CB transect in December. In contrast, light trap catches of these families were dominated by samples from a single station on the LR transect in October. Net-tow collections showed that smali pomacentrid and mullid larvae were almost absent at this station. Clupeids similarly showed no relationship between catch rates of the net tows and those in the light traps (Fig. 9). Small larvae collected in net tows were found in high numbers at outer-lagoon stations on the LR transect, and across all stations in December. Light trap catches were dominated by catches at the inshore station on the LR transect in October. We conclude that there is little correlation between the distribution patterns of the families as revealed by net tows and light traps.

\section{DISCUSSION}

Larval distributions determined from the plankton net tows revealed a comparatively stable spatial pattern, with a distinctive inshore ichthyoplankton assem- 
Fig. 9. Mean numbers $1+$ standard error) of larvae captured by plankton nets (left axes, solid bars) and light traps (right axes, hatched bars) at stations across the central Great Barrier Reef on the $L R$ and $C B$ transects, October to December 1989, for the families Pomacentridae, Clupeidae and Mullidae
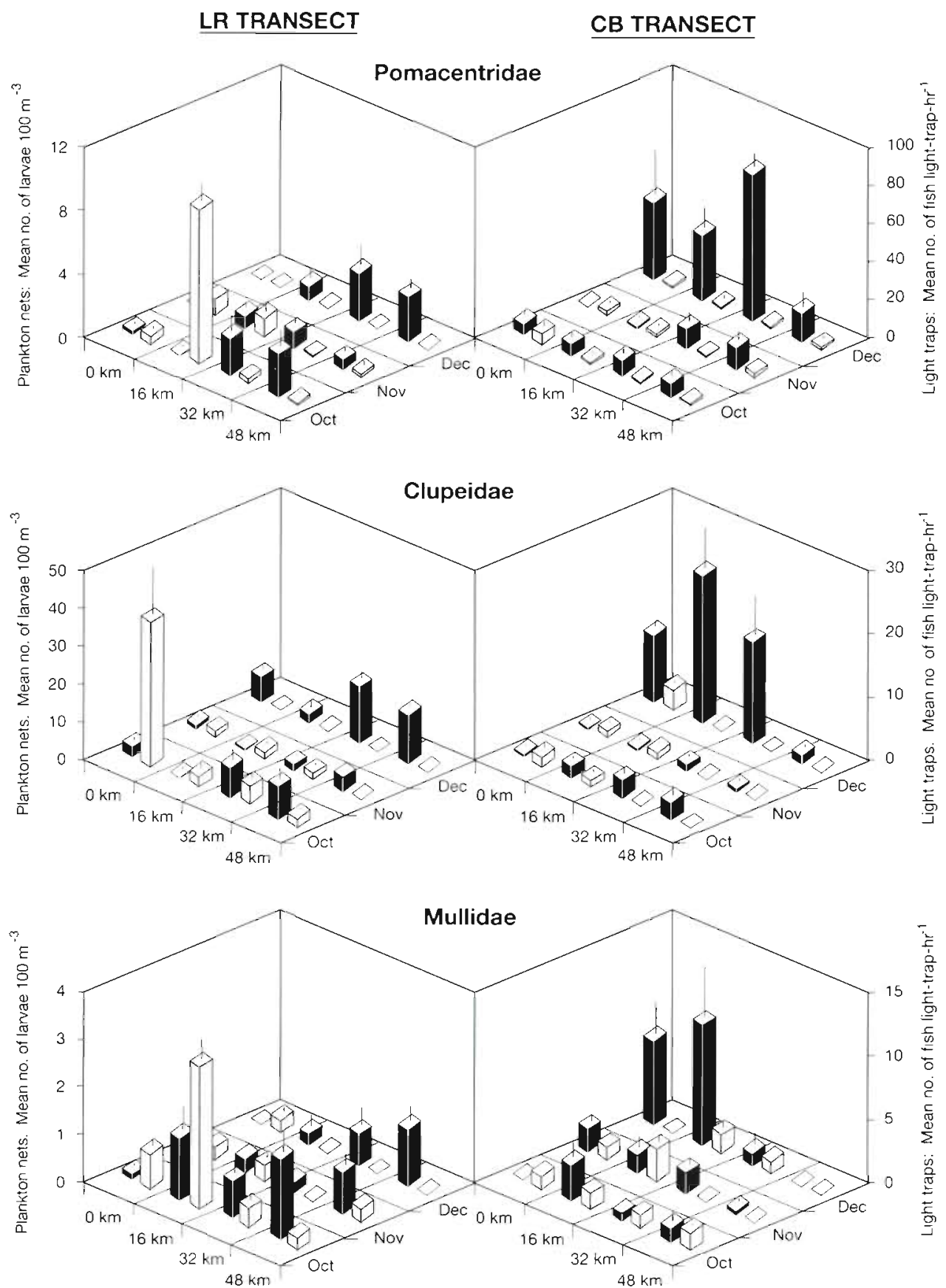

blage captured at the inshore station, a cross-lagoonal assemblage found across all stations, and an outerlagoon assemblage represented at the 3 offshore locations. Milward \& Hartwick (1986) also noted the presence of 3 distinct family groupings across the central GBR lagoon, corresponding to nearshore, cross-lagoon and outer-lagoon communities. That study was based solely on presence/absence data, but the present study largely confirms their results. While the nearshore larval fish community was restricted to the $0 \mathrm{~km}$ station in 1989, the distribution patterns of total fish larvae from
1988 suggests that this community may have been present at the $8 \mathrm{~km}$ station also (Thorrold 1992b). Milward \& Hartwick (1986) suggested that the demarcation between inshore and offshore family groups occurred at approximately $10 \mathrm{~km}$ off the coast.

Several potential mechanisms may act to maintain larval assemblages within the different water masses. The simplest explanation is that, in the absence of significant cross-lagoon water exchange, the assemblages reflect the distribution of spawning adults across the shelf. Zooplankton distributions provide a 
test for the degree of cross-lagoon water movements as they are often closely linked to current regimes (Mackas \& Sefton 1982), and may be useful as lagrangian tracers of water movement (Thomas 1992). Sammarco \& Crenshaw (1984) found considerable cross-lagoon movement of the inshore zooplankton assemblage in the central GBR lagoon. However they also noted considerable inter-annual variability in this movement, with significant cross-lagoon movement being associated with large amounts of riverine input into near-coastal waters. McKinnon \& Thorrold (1993) argued that zooplankton distributions were even more dynamic than suggested by Sammarco \& Crenshaw's (1984) study. Zooplankton assemblages across the central GBR lagoon were coupled with the position and strength of a shear zone across the lagoon caused by interactions between the East Australian Current, prevailing wind conditions, and frictional effects due to bathymetry (King \& Wolanski 1992). Inshore plankton assemblages are trapped along the coast by the coastal boundary layer when alongshore current velocities are sluggish, but are located up to $24 \mathrm{~km}$ from the coast when alongshore velocities are high in either direction. Larval fish assemblages did not show this same pattern, as inshore assemblages were only rarely found at the $16 \mathrm{~km}$ station. Both the inshore and outer-lagoon assemblages appeared more tightly linked to turbidity gradients, apparently driven by bottom re-suspension, than by the position of the shear zone (Thorrold 1993b). Assuming that zooplankton are better tracers of water mass movements than larval fish, it would appear that hydrodynamic separation cannot explain maintenance of distinctive larval fish assemblages across the inner GBR lagoon.

While hydrographic separation does not appear to account for the larval fish assemblages across the inner lagoon, several biological processes may be maintaining these patterns. Differential mortality, due to either high turbidity (in the inshore water mass) or food levels (low in the offshore water mass) may act to selectively remove fish larvae from either water mass type. Alternatively, larvae may actively avoid moving between the different water masses. While both hypotheses are plausible, we are unlikely to be able to test either without a greater understanding of larval taxonomy as survival rates in each of the water masses will need to be measured to test these ideas. Larval fish mortality is notoriously difficult to quantify under optimal conditions, and indeed there are no survivorship estimates for any coral reef fish larvae (Leis 1991a). It may prove more practical to examine early life history scans of otoliths using electron or laser microprobes to determine if larvae are indeed making significant crosslagoon excursions (Radtke 1988, Thorrold et al. in press).
Although spatial variability dominated the net tow data, there was also a significant temporal effect. In December, for instance, a number of taxa, including lutjanids, nemipterids, pomacentrids and mullids, showed large increases at offshore stations on both transects. The coherence of taxa argues that the processes generating this pattern were acting over synoptic scales at least $50 \mathrm{~km}$ in both cross-lagoon and alongshore directions. It is possible that events in the planktonic environment enhanced larval survival of all the families. Increased primary productivity over similar scales has been documented due to an intrusion of cold, nutrient-rich water from the Coral Sea (Furnas \& Mitchell 1987). Enhanced primary production during these intrusions causes increased secondary productivity (Mckinnon \& Thorrold 1993), which may also lead to lower mortality rates of larval fish due to reduced starvation or increased growth. The other major source of nutrient-rich water in the central GBR lagoon comes from accasional large freshwater discharge events (Wolanski \& Jones 1981) Flow records from the Burdekin River, which is the largest source of freshwater into the central GBR lagoon (Sammarco \& Crenshaw 1984), showed no significant freshwater discharge at this time. It is perhaps more likely that this effect was the result of spawning activities over these spatial scales, although there is surprisingly little known about the spawning habits of shorefishes in this region.

Distribution patterns of small fishes captured in the light traps were much more transitory than those of the plankton nets. Catches were dominated by late-stage larval reef fish taken at a single station in October In the previous year, Thorrold (1992a) also detected a single 'patch' of reef fish larvae while sampling over the same months across the inner half of the central GBR lagoon. In that year the patch was located in the middle of the lagoon on the CB transect over $4 \mathrm{~d}$ in December. Pomacentrids of the genus Pomacentrus also dominated catches in the earlier year, although lethrinids were rare throughout sampling in the earlier year. The fact that only one 'patch' was detected in each of the years suggests such patches are a relatively rare occurrence, albeit numerically extremely important. Indeed the light trap data in this study appear similar in some respects to those from moored light traps around Lizard Island (Milicich 1992). Milicich noted an extremely large pulse of settlement-stage larvae in 1988 that was not repeated in 3 subsequent years of monitoring. Taken together, these data appear consistent with the hypothesis that major settlement events occur when occasional dense patches of larvae collide with reef habitats (Victor 1984, Williams 1986).

Meso-scale multi-specific patches of reef fish larvae may be formed by several mechanisms. Victor (1984) 
suggested that the arrival of a patch of bluehead wrasse Thalassoma bifasciatum larvae generated a settlement pulse that was synchronous over a number of reefs separated by as much as $50 \mathrm{~km}$. He argued that since the newly settled juveniles had variable planktonic durations, a single spawning event (e.g. Canino et al. 1991, Davis et al. 1991) was unlikely to have generated the observed settlement pattern. We found that the extremely patchy distribution patterns of latelarval and pelagic juvenile pomacentrids and mullids collected by the light traps were not reflecting the distributions of smaller pomacentrid and mullid larvae taken in plankton nets. This also suggests that a synchronous spawning event is unlikely to have played a significant role in patch formation of reef fish larvae in the study area. Williams \& English (1992) hypothesized that the presence of a cold-core eddy may have led to anomalously high concentrations of larval fish in the vicinity of Myrmidon Reef, on the outer shelf of the central GBR. Meso-scale eddies have been shown to aggregate pelagic (Thomson et al. 1992) and mesopelagic fishes (Olson \& Backus 1985), and the convergence associated with eddies and coastal fronts may entrain fish larvae due to passive aggregation (Kingsford 1990). We found that the stations with high light trap catches were, in both the present study and that of the previous year (Thorrold 1993a), associated with low numbers of larval fishes collected in plankton nets. If patches were formed by passive aggregation at a physical discontinuity we would also expect large numbers of small larvae to be found along with the larger larvae and juveniles. Small larvae are indeed more likely to be susceptible to entrainment by oceanographic features such as convergence zones due to limited locomotory abilities. It is possible that ontogenetic changes in behaviour make late-stage larvae more likely to be passively accumulated in features such as frontal zones. Alternatively, these larvae may be actively aggregating at physical oceanographic features to take advantage of higher productivity in these features (LeFevre 1986). A higher resolution sampling design, measuring physical and biological variables, will be needed to distinguish between these hypotheses.

Unfortunately logistic constraints meant that the spatial dimensions of the patches determined from the light trap data could not be mapped quasi-synoptically (e.g. Incze et al. 1989). Patch sizes of reef fish larvae have been inferred from settlement studies to be approximately 30 to $50 \mathrm{~km}$ (Victor 1984, Williams 1986 , Doherty 1987 b). Only one study has provided a direct measurement of the patch dimensions of coral reef fish larvae from ichthyoplankton tows. Williams \& English (1992) concluded that a patch of larvae sampled in net tows near Myrmidon Reef, off the coast near Towns- ville, was at least $7 \mathrm{~km}$ wide. In the present study, the one patch found was confined to the $16 \mathrm{~km}$ station on the LR transect, so we can only say with confidence that patch dimensions were less than $32 \mathrm{~km}$ in the cross-shelf direction. Cross-shelf dimension of such patches may be relatively small, as Parslow \& Gabric (1989) found in a modelling study that parcels of neutrally buoyant particles in this area tended to form 'streaks' that aligned parallel to the long-shore currents. Synoptic mapping of patch dimensions using light trap arrays would appear to be the only way to determine patch size in a definitive manner.

Acknowledgements. Thus work was funded in part by the Monkman Fellowship, awarded by the Department of Marine Biology at James Cook University (to S.R.T.), and by the Australıan Institute of Marine Science. Jeff Leis and Tom Trnski helped with the identification of a number of problematic larvae. Comments by Peter Doherty, Ed Houde, Jeff Leis and Bill Richards, and by 2 anonymous reviewers, improved earlier drafts of this work. We thank Hugh Layton and John Sharp, skippers of the RV 'Pegasus', for their expert assistance, and a number of volunteers who helped with the collections, often in trying conditions. This is contribution no. 767 of the Australian Institute of Marine Scjence.

\section{LITERATURE CITED}

Barkley RA (1964) The theoretical effectiveness of towed-net samplers as related to sampler size and to swimming speed of organisms. J Conseil 29:146-157

Belbin L (1988) Pattern analysis package reference manual. Division of Wildlife and Rangelands Research, CSIRO. Canberra

Boehlert GW, Watson W, Sun LC (1992) Horizontal and vertical distributions of larval fishes around an isolated oceanic island in the tropical Pacific. Deep Sea Res 39:439-466

Canino MF, Bailey KM, Incze LS (1991) Temporal and geographic differences in feedng and nutritional condition of walleye pollock larvae Theragra chalcogramma in Shelikof Strait, Gulf of Alaska. Mar Ecol Prog Ser 79:27-35

Choat JH, Doherty PJ, Kerrigan B, Leis JM (1993) Larvae and pelagic young of coral reef fishes: comparison of three towed nets, a purse seine and two light aggregation devices. Fish Bull US 91:195-209

Clarke TA (1983) Comparison of abundance estimates of small fishes by three towed nets and preliminary results of the use of small purse seines as sampling devices. NOAA Tech Rep NMFS 101

Davis TLO, Lyne V, Jenkins GP (1991) Advection, dispersal and mortality of a patch of southern bluefin tuna larvae Thunnus maccoyii in the East Indian Ocean. Mar Ecol Prog Ser 73:33-45

Doherty PJ (1987a) Light traps: selective but useful devices for quantifying the distributions and abundances of larval fishes. Bull Mar Sci 41:423-431

Doherty PJ (1987b) The replenishment of populations of coral reef fishes, recruitment surveys, and the problems variability manifest on multiple scales. Bull Mar Sci 41 $411-422$

Furnas MJ, Mitchell AW (1987) Phytoplankton dynamics in the central Great Barrier Reef - II. Primary production. 
Cont Shelf Scl 7:1049-1062

Cicgory RS, Powles PM (1988) Relative selectivities of Miller high-speed samplers and light traps for collecting ichthyoplankton. Can J Fish Aquat Sci 45:993-998

1 fiort $\mathrm{J}$ (1914) Fluctuations in the great fisheries of northern Europe. Rapp PV Reun Cons Int Explor Mer 20:1-228

Houde ED (1987) Fish early life dynamics and recruitment variability. Am Fish Soc Symp 2:17-29

Inzce LS, Kendall AW, Schumacher JD, Reed RK (1989) Interactions of a meso-scale patch of larval fish (Theragra chalcogrammal with the Alaska Coastal Current. Cont Shelf Sci 9:169-284

King B, Wolanski E (1992) Coastal dynamics along a rugged coastline. In: Prandle D (ed) Dynamics and exchanges in estuaries and the coastal zone. Springer Verlag, New York, p 577-598

Kingsford MJ (1990) Linear oceanographic features: a focus for research on recruitment processes. Aust $J$ Ecol 15: $391-401$

Kobayashi DR (1989) Fine-scale distributıon of larval fishes: Patterns and processes adjacent to coral reefs in Kaneohe Bay, Hawall. Mar Biol 100:285-29

LeFevre J (1986) Aspects of the biology of frontal systems. Adv Mar Biol 23:163-299

Legendre P, Fortun MJ (1989) Spatial pattern and ecological analysis. Vegetatio 80:107-138

Leis JM (1991a) The pelagic stage of reef fishes: the larvae biology of coral reef fishes. In: Sale PF (ed) The ecology of fishes on coral reets. Academic Press, San Diego, p $183-230$

Leis JM (1991b) Vertical distribution of fish larvae in the Great Barrier Reef lagoon, Australia. Mar Biol 109: $157-166$

Leis JM, Rennis DS (1983) The larvae of [ndo-Pacific coral reef fishes. NSW Univ Press, Sydney

Leis JM. Trnskl T (1989) The larvae of Indo-Pacific shorefishes. NSW Univ Press, Sydney

Lyczkowsk1-Shultz J, Ruple DL, Richardson SL, Cowan JR (1990) Distribution of fish larvae relative to time and tide in a Gulf of Mexico barrier island pass. Bull Mar Sci 46 : $563-577$

McCormick MI, Shand J (1992) Metamorphosis of the visual and barbel sensory systems at settlement in the roof fish Upeneus tragula (Family Mullidae). Proc 7th Int Coral Reef Eish Symp 1:616-623

Mackas DL, Sefton HA (1982) Plankton species assemblages off southern Vancouver Island: geographic pattern and temporal variabuluty. J Mar Res 40:1173-1200

Mackas DL, Dnnman KL, Abbott MR (1985) Plankton patchiness: biology in the physical vernacular Bull Mar Sci 37 : $652-674$

McKinnon AD, Thorrold SR (1993) Zooplankton community structure and copepod egg production in coastal waters of the central GBR lagoon. J Plankton Res 15:1387-1411

Maillet GL. Checkley DM (1991) Storm-related variation in the growth rate of otoliths of larval Atlantic menhaden Brevoortia tyrannus: a time serles analysis of bıological and physical variables and implications for larval growth and mortality. Mar Ecol Prog Ser 79:1-16

Mantel N (1967) The detection of disease clustering and a generalized regression approach. Cancer Res 27:209-220

Milicich MJ (1992) Light traps: a novel technique for quanti. fying larval supply and replenishment of coral rent fish populations. PhD dissertation, Griffith University, Brisbane

Milicich MJ, Doherty PJ (1994) Larval supply of coral reef fish populations: magnitude and synchrony of replenishment to Lizard Island. Mar Ecol Prog Ser 110:121-134

Milward NE, Hartwick RF (1986) Temporal and spatial distribution of. fish larvae across the continental shelf lagoon of the central Great Barrier Reef. In: Uyeno T, Araı R, Taniuchi $\mathrm{T}$, Matsuura $\mathrm{K}$ (eds) Indo-Pacific fish biology: Proceedings of the Second International Conference on IndoPacific Fishes. Ichthyological Society of Japan, Tokyo, p $748-758$

Munk, P (1988) Catching large herring larvae: gear applicability and larval distribution. J Cons Int Explor Mer 45: $97-104$

Omori M. Hamner WM (1982) Patchy distribution of zooplankton: behavior, population assessment and sampling problems. Mar Biol 72:193-200

Olson DB, Backus RH (1985) The concentrating of organisms at fronts: a cold-water fish and a warm-core Gulf Stream ring. J Mar Res 43:113-137

Parslow JS, Gabric AJ (1989) Advection, dispersal and plankton patchiness on the Great Barrier Reef. Aust J Mar Freshwater Res 40:403-419

Peterman RM, Bradford MJ (1987) Wind speed and mortality rate of a marine fish, the northern anchovy (Engraulis mordax). Science 235:354-356

Radtke RL (1988) Recruitment parameters resolved from structural and chemical components of juvenile Dascyllus albisella otoliths. Proc 6th Int Coral Reef Symp 2:821-826

Roughgarden J, Gaines S, Possingham H (1988) Recruitment dynamics in complex life cycles. Science 241:1460-1466

Sammarco PW, Crenshaw H (1984) Plankton community dynamics of the central Great Barrier Reef lagoon: analysis of data from Ikeda et a]. Mar Biol 82:167-180

Smith RW, Bernstein BB, Cimberg RL (1989) Communityenvironmental relationships in the benthos: applications of multivarlate analytical techniques. In: Soule DF, Kleppel GS (eds) Marine organisms as indicators. SpringerVerlag, Berlin, p 248-326

Smouse PE, Long JC, Sokal RR (1986) Multiple regression and correlation extensions of the Mantel test of matnx correspondence. Syst Zool 35:627-632

Thomas AC (1992) Spatial patterns of zooplankton community composition and satellite measured surface temperature. Cont Shelf Sci 12:753-777

Thomson RE, Healey MC, Morris JFT, Borstad GA (1992) Commercial troll fishing vessel distribution off Vancouver Island during July 1988: relation to observed physical oceanography. Can J Fish Aquat Sci 49:820-832

Thorrold SR (1992a) Evaluating the performance of light traps for sampling small fish and squid in open waters of the central Great Barrier Reef lagoon. Mar Ecol Prog Ser 89: $277-285$

Thorrold SR (1992b) Coupling of hydrography and pre-settlement reef fish distributions in the central Great Barrier Reef lagoon. Proc 7th Int Coral Reef Symp 1:629-635

Thorrold SR (1993a) Post-larval and juvenile scombrids captured in light traps; preliminary results from the central Great Barrier Reef lagoon. Bull Mar Sci 52:631-641

Thorrold SR (1993b) Meso-scale distribution patterns of larval fishes across the central Great Barrier Reef lagoon and relationships with environmental variability. PhD dissertation, James Cook University of North Queensland

Thorrold SR, Jones CM, Campana SE (in press) Response of otolith microchemistry to environmental variations expenenced by larval and juvenile Atlantic croaker (Micropogonlas undulatus!. Limnol Oceanogr

Victor BC (1984) Coral reef fish larvae: patch size estumation and mixing in the plankton. Limnol Oceanogr 29 11161119 
Williams DMcB (1986) Spatial and temporal scales of processes determining inter-annual variation in recruitment of fishes in the Great Barrier Reef: some preliminary data. IOC Rep Suppl 44:229-239

Williams DMcB, English S (1992) Distribution of fish larvae around a coral reef: direct detection of a meso-scale,

This article was submitted to the editor multi-specific patch? Cont Shelf Scl 12:923-937

Winer B (1971) Statistical principles in experimental design, 2nd edn. McGraw-Hill, New York

Wolanski E, Jones M (1981) Physical properties of Great Barrier Reef lagoon waters near Townsville. I. Effects of Burdekin Rıver floods. Aust J Mar Freshwater Res 32:305-319

Manuscript first received: October 20,1995

Revised version accepted: May 15, 1996 